\title{
TEMPERATURE AND SOMATIC GROWTH EFFECTS ON OTOLITH GROWTH OF LARVAL ATLANTIC MENHADEN, BREVOORTIA TYRANNUS (ACTINOPTERYGII: CLUPEIFORMES: CLUPEIDAE)
}

\author{
Dariusz P. FEY ${ }^{1 *}$ and Jonathan A. HARE ${ }^{2}$ \\ ${ }^{1}$ Department of Fisheries Oceanography and Marine Ecology, National Marine Fisheries Research Institute, \\ Gdynia, Poland \\ ${ }^{2}$ NOAA Narragansett Laboratory, Narragansett, RI 02882, USA
}

Fey D.P., Hare J.A. 2012. Temperature and somatic growth effects on otolith growth of larval Atlantic menhaden, Brevoortia tyrannus (Actinopterygii: Clupeiformes: Clupeidae). Acta Ichthyol. Piscat. 42 (3): $215-222$.

Background. If a link exists between somatic and otolith growth, otolith size and microstructure analysis can be a useful tool in studies of larval fish growth and condition - methods like growth back-calculation or marginal increment width analysis can be employed. Because significance of that link may vary among species and can be additionally modified by temperature, the aim of the present paper is to evaluate how sagittal otoliths of Atlantic menhaden responded to somatic growth and temperature.

Materials and methods. Larval Atlantic menhaden, Brevoortia tyrannus (Latrobe, 1802) (age range: 20-120 days; length range: 14-35 mm SL), collected during 3 years were evaluated for length-at-age and groups of the shortest and longest-at-age individuals ( $8 \%$ of sampled population in each group) were used in the analyses. Similarly, otolith size-at-age estimated from sagittae length was evaluated and then compared with the earlier estimated growth indices of larvae.

Results. Otolith growth rate (OGR) indicated growth differences among analysed larvae. Additionally, temperature effect on OGR independent of somatic growth was detected for larvae that were short-at-age (i.e., the slow growth group). For the fast grow group, temperature effect on OGR was insignificant.

Conclusion. Back-calculation of growth from otoliths of larval and early juvenile Atlantic menhaden is justified but less accurate estimates can be expected for the slowest growing individuals due to the independent temperature effect on otolith growth.

Keywords: Brevoortia tyrannus, fish larvae, menhaden, otolith growth, somatic growth

\section{INTRODUCTION}

Recruitment success in the majority of marine fish populations is determined by processes occurring during larval and juvenile stages (Houde 1987, Anderson 1988). To investigate the complex processes affecting recruitment success, appropriate methods are needed to quantify growth, predation, starvation, and the characteristics that distinguish survivors from the vast majority of individuals that perish (Fuiman and Werner 2002). A set of methods exist based on fish otoliths, which are biogenic calcium carbonate structures involved in fish hearing and orientation (Campana and Neilson 1985, Campana 2005). These otoliths applications include the back-calculation of growth rate (Francis 1990), using the series of increment widths to estimate growth trajectories (Maillet and Checkley 1991, Paperno et al. 1997, Wang and Tzeng 1999, Oozeki and Watanabe 2000), measuring marginal increment width to estimate recent growth rate (Fey 2005, Aguilera et al. 2009), and comparison of growth rates or size-at-age back-calculated for older (i.e., survivors) and younger (i.e., original population) specimens, which allows for growth-dependent survival evaluation (Meekan and Fortier 1996, Hare and Cowen 1997, Takasuka et al. 2004).

Although much effort has been directed towards identifying the best methods to estimate fish size and growth from otolith size and growth (Secor and Dean 1992, Sirois et al. 1998, Morita and Matsuishi 2001, Finstad 2003), questions remain about the true relation between somatic and otolith growth rates. A common assumption is that high correlation between otolith size and somatic size at population level implies a high correlation between otolith growth and fish growth at individual level. This assumption, however, is not necessarily true. Several studies have found that the otolith size-somatic size rela-

\footnotetext{
* Correspondence: Dr Dariusz P. Fey, Zakład Oceanografii Rybackiej i Ekologii Morza, Morski Instytut Rybacki - Państwowy Instytut Badawczy, ul. Kołłataja 1, 81-332 Gdynia, Poland, phone: +48 587-356-232, fax: +48 587-356-110, e-mail: dfey@mir.gdynia.pl.
} 
tion can be affected by other factors (e.g., the rate of somatic growth and temperature, Mosegard et al. 1988, Secor et al. 1989, Fey 2001, 2006, Takasuka et al. 2008). In addition, Thorrold and Hare (2002) demonstrated in a simple simulation that otolith and somatic size could be positively correlated even if the relation between otolith and somatic growth is negative. Otolith growth can also continue in the absence of somatic growth resulting in a weakening of the relation between fish- and otolith size (Sogard 1991, Folkvord et al. 2004, Molony and Choat 2006). Thus, applying otolith techniques to estimate size and growth of larval and juvenile fish requires knowledge of the dependence of otolith growth on somatic growth and the role of other factors on this relation such as temperature and ontogeny (e.g., Hare and Cowen 1995, Paperno et al. 1997, Tonkin et al. 2008, Aguilera et al. 2009).

Atlantic menhaden, Brevoortia tyrannus (Latrobe, 1802), is important as a fishery target and as prey for many fish and birds. It ranges, on the east coast of the United States, from the central coast of Florida to Nova Scotia and spawns in continental shelf waters almost year round (Reintjes, unpublished*). Peak spawning, however, is south of Cape Hatters and along North Carolina coast during winter (Reintjes, unpublished*). Regarding otolith microstructure analysis, Maillet and Checkley (1990) and Ahrenholz et al. $(1995,2000)$ demonstrated that increments form daily in the otoliths of larvae and juveniles kept under different temperature and feeding conditions, even at temperatures $<3^{\circ} \mathrm{C}$, in which increment widths fall below $1 \mu \mathrm{m}$. Ahrenholz et al. (1995) concluded that daily increments provide an accurate estimate of age of menhaden up to 200 days. Further, Maillet and Checkley (1990) demonstrated that otolith growth differed between captive larvae up to 35 days of age subjected to feeding treatments, suggesting a relation between otolith growth and somatic growth. No validation for somatic growthotolith growth relation has been conducted for older captive menhaden and none for a free living Atlantic menhaden. As shown by Fey (2006) for two pelagic species co-occurring in the same environment (herring and smelt), there is a necessity to evaluate the somatic growth effect on otolith growth independently for each species. Therefore, there is still a need for such study for Atlantic menhaden.

The goals of this work were to evaluate the relation between otolith growth and somatic growth of wild larval Atlantic menhaden and to assess if and when temperature affects this relation.

\section{MATERIALS AND METHODS}

Our goals were achieved through five steps: 1) collect and age menhaden larvae, 2) select a subset of fast- and slow growers, 3) estimate temperature histories of fish from this subset, 4) determine otolith size for fish from this subset, and 5) analyze the otolith growth-somatic growth relation and assess the effects of growth and temperature on this relation.

Fish collection. Larval Atlantic menhaden were collected using a neuston net with a $2-\mathrm{m}^{2}$ opening $(2 \times 1 \mathrm{~m})$ and 947- $\mu \mathrm{m}$ mesh deployed from a bridge platform at Pivers Island, North Carolina from October through April $1992 / 93$, 1993/94, and 1997/98 as they entered the Newport River estuary (see Warlen 1994). Larvae were preserved in $90 \%$ alcohol immediately after the tow. A length correction formula (Fey and Hare 2005) was used to calculate the live length of collected larvae. A subsample of preserved fish from each sampling day was measured to the nearest $0.01 \mathrm{~mm}$ (SL) providing a total of $>2000$ fish measured for the 3-year study.

Fish aging. Sagittal otoliths were extracted from the entire subsample of fish, cleaned in distilled water, and mounted on glass slides with DePeX mounting medium (Electron Microscopy Sciences, Fort Washington, PA). No additional otolith preparation was necessary. Increments were counted three times on different occasions using a light microscope $(\times 400$ or $\times 1000)$ and image analysis system (Optimas 6.0). The sample was excluded if the difference in increment counts exceeded $10 \%$; otherwise the average of the three counts was used to estimate age. A total of 1862 fish was successfully aged. A correction factor of 5 days was added to all age estimates to account for the time between spawning and first increment formation (Warlen 1992).

Selection of fast and slow growers. The length-atage data (age range: 20-120 days; length range: 14-35 $\mathrm{mm} \mathrm{SL}$ ) for all years were pooled and fit with a polynomial function using generalized regression model (GLM) (Fig. $1, n=1.862, r^{2}=0.708$ ). The residuals of lengths-atage from the polynomial fit describe deviation from expected values for each individual. We view these deviations as a measure of the difference of growth of the individual from the population growth trend. The absolute values of the residuals $(\mathrm{mm})$ were then converted to a percentage of the average length-at-age to allow for the pooling of residuals across different ages. Based on these residuals, two length-at-age groups of larvae were established which we interpret as slow growing (residuals $<-8 \%$ ) and fast growing (residuals $>8 \%$ ). Slow and fast growing fish were identified from a combined for all three years dataset. Such procedure of distinguishing two growth rate groups was related to requirements of another study for which the data were used.

Temperature histories. The approximate temperature experienced by each individual was calculated as an average value of: a) temperature at the time of collection, b) temperature at the time of $2 / 3$ of the age at collection, and c) temperature at hatch. The approximate temperature at hatch was estimated from equation based on reported temperatures during spawning season $(18.767-0.0126$. $H_{j}+0.0003 \cdot H_{j}^{2}-0.0000007381 \cdot H_{j}^{3}$; where $H_{j}$ is the Julian day i.e., day-of-the-year of hatch) (Warlen 1992, Quinlan et al. 1999, Stegmann et al. 1999). Individual hatch dates were back calculated as sampling-date minus age. The calculated temperature at hatch varied between 18.1 (February) and $22.8^{\circ} \mathrm{C}$ (October). The temperature at collection and $2 / 3$ of the age at collection were estimated from equations describing temperature variations within 


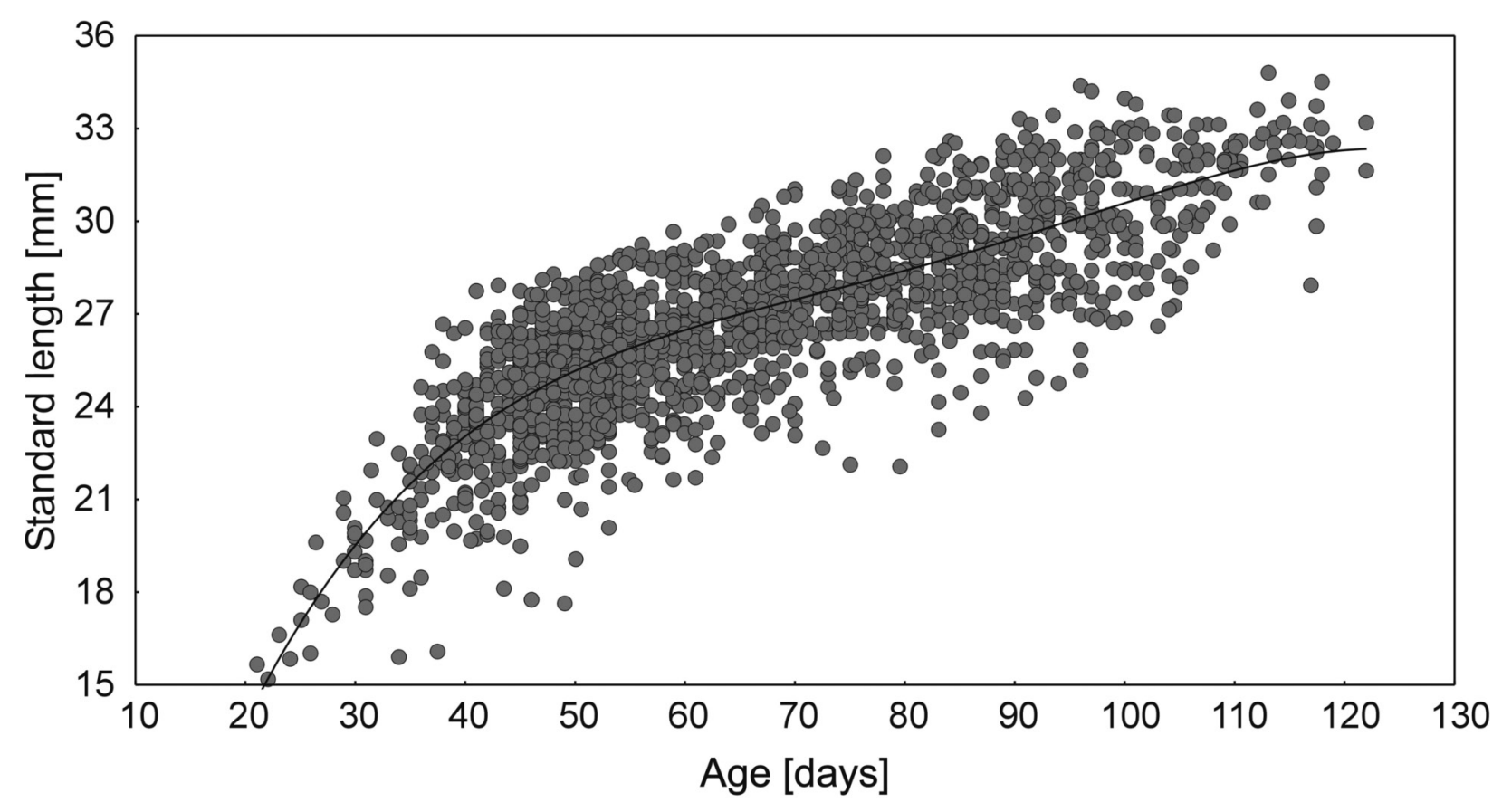

Fig. 1. Relation between standard length (SL) and age $(A)$ of larval Atlantic menhaden, Brevoortia tyrannus (collected from October through April 1992/93, 1993/94, and 1997/98), described with polynomial function (SL = $-8.0126+1.55 A-0.0271 A^{2}+0.0002 A^{3}-0.00000065263 A^{4} ; n=1865 ; r^{2}=0.708$ )

a given sampling year (temperature measured daily inside the estuary were larvae were collected). It was assumed that the temperature measured inside estuaries corresponds relatively well to temperature near shore, at the entrance to the estuary, i.e., temperature experienced when larvae reach $2 / 3$ of the age. Support for this assumption may be found in Stegmann et al. (1999) presenting satellite temperature maps and modelled distribution of menhaden larvae recruiting to the Beaufort River (and some others) estuary, as well as some temperature histories for different cohorts of larvae. Despite the obvious crudeness of the calculation, our approach captures much of the region's seasonal temperature variability experienced by larvae recruiting over extensive period of time. Larvae advected from further north would have experienced cooler temperatures, but this latitudinal variability is small relative to the seasonal variability (Stegmann et al. 1999) and therefore is excluded here. The calculated average experienced temperatures varied between 11.9 and $19.1{ }^{\circ} \mathrm{C}\left(\right.$ Mean $\left.=15.2^{\circ} \mathrm{C}, \mathrm{SD}=1.61\right)$ and corresponded well to temperature histories presented for different cohorts by Stegmann (1999).

Otolith growth determination. Otolith size (length) from 269 larvae assigned to the high and low growth rate index groups were measured (the nearest $0.1 \mathrm{~mm}$ using an image analysis system (Optimas 6.0). The otolith size-atage data were described with an exponential function (Fig. 2) and the residuals from that model were used as the parameter describing otolith growth rate (OGR). As with $\mathrm{SL}$ of fish, the residuals of otolith size-at-age from the exponential fit describe deviation from expected values for each individual. We view these deviations as a meas- ure of the difference of growth of the otolith from the population growth trend. The absolute values of the residuals $(\mathrm{mm})$ were then converted to a percentage of the average otolith size-at-age to allow for the pooling of residuals across different ages. Additionally, a group of 30 otoliths was measured three times to estimate the error related to the precision of otolith size measurement (average $\mathrm{CV}=$ $0.69 \% ; \mathrm{CV}=\mathrm{SD} /$ mean $\times 100$ ).

Data analysis. In addition to describing the OGRSGR and OGR-Temperature data with simple linear regressions, 3-way factorial ANOVA was used to evaluate the temperature $\left(T<15^{\circ} \mathrm{C}\right.$ and $\left.\mathrm{T}>15^{\circ} \mathrm{C}\right)$, somatic growth (High-GR group and Low-GR group, residuals), and year (92/93, 93/94, and 97/98) effect on otolith growth. All the statistical comparisons were carried out using Statistica ${ }^{\circledR}$ 6.0. (StatSoft).

\section{RESULTS}

Otolith growth rate (OGR) (otolith length-on-age residuals) was significantly affected by somatic growth (SGR) (SL-on-age residuals), as indicated by the fitted to OGR-SGR data regression line $\left(r^{2}=0.761, P<0.005\right)$

(Fig. 3). It is also noticeable that almost all the otoliths from low-growth-rate group grew with a rate below the mean and similarly, almost all otoliths from high-growthrate group grew with a rate above the mean value. This method based on using residuals as fish and otolith growth indices allowed for accounting for the observed in Figs. 1 and 2 fish and otolith growth dependence on fish age.

OGR was significantly affected not only by SGR (HighGR group and Low-GR group), but also by temperature $\left(>15^{\circ} \mathrm{C}\right.$ and $\left.<15^{\circ} \mathrm{C}\right)$ - similar way within each of the three 
analysed year (92/93, 93/94, and 97/98) (3-way ANOVA; Table 1; Fig. 4). The somatic growth effect has been the most pronounced. The temperature effect was independent from the year effect (i.e., temperature affected OGR the same way in each year). The SGR-effects interacted with temperature and year, which indicates that otolith growth is affected differently by temperature between the two somatic growth groups - temperature affected significantly OGR only in slow growing larvae (Fig. 4).

So to more precisely evaluate the difference in temperature effect on otolith growth between GR groups, the OGR was plotted against values of experienced by individual fish temperatures, separately for the two growthrate groups (Fig. 5). The results confirmed that at high somatic growth, temperature does not affect OGR (regression line, $\left.r^{2}=0.021, P=0.061\right)$, but at low somatic growth, OGR increases with increasing temperature (regression line, $r^{2}=0.320, P<0.005$ ).

\section{DISCUSSION}

There are multiple methods for measuring growth rate and condition of early life stages of fish, including methods that evaluate morphology (Theilacker 1986, McCormick and Molony 1992), histology (Theilacker 1986), overall and constituent lipid composition (Håkanson 1989), protein levels (Folkvord et al. 1996), RNA to DNA ratios (Clemmesen 1988), fluctuating asymmetry of body parts (Palmer 1994), and otolith microstructure (Campana and Neilson 1985). The ability of otoliths for use in fluctuating asymmetry (FA) analysis to discriminate between natural variability of growth and condition of larval Atlantic menhaden was evaluated (Fey and Hare 2008) using the same fish used in the present work. The FA analysis was ineffective in discriminating between growth rates groups. The analyses conducted here addressed the otolith microstructure analysis method. Assuming the existence of significant relation between otolith growth and somatic growth, it is possible to back-calculate fish size at a given age. From these growth estimates, it is possible to generate individual-fish growth trajectories from measurements of increment widths. Existence of relation between fish growth-otolith growth (as distinct from a relation between fish size-otolith size relation) has been found documented by many authors (e.g., Maillet and Checkley 1990, Mugiya and Oka 1991, Paperno et al. 1997, Tonkin et al. 2008), even if time lags may sometimes exist (Molony and Choat 2006). Recently, Aguilera et al. (2009) found that for European bass, Dicentrarchus labrax (L.), larvae that the width of the outermost otolith increments reflect the past feeding history and that the recent otolith growth index can be used to distinguish well fed from poorly fed larvae. Results of the above studies are in agreement with the main conclusion of the current research-otolith growth dependence on somatic growth - and support the value of using otoliths in somatic growth analysis

Despite the evidence supporting the existence of a significant relation between fish growth and otolith growth, species- or environment-related differences can be expected. For example, Fey (2006) showed that the same environmental conditions (temperature and zooplankton) affect otolith growth differently in two co-occurring pelagic species, European smelt, Osmerus eperlanus (L.), and Atlantic herring, Clupea harengus L. For smelt,

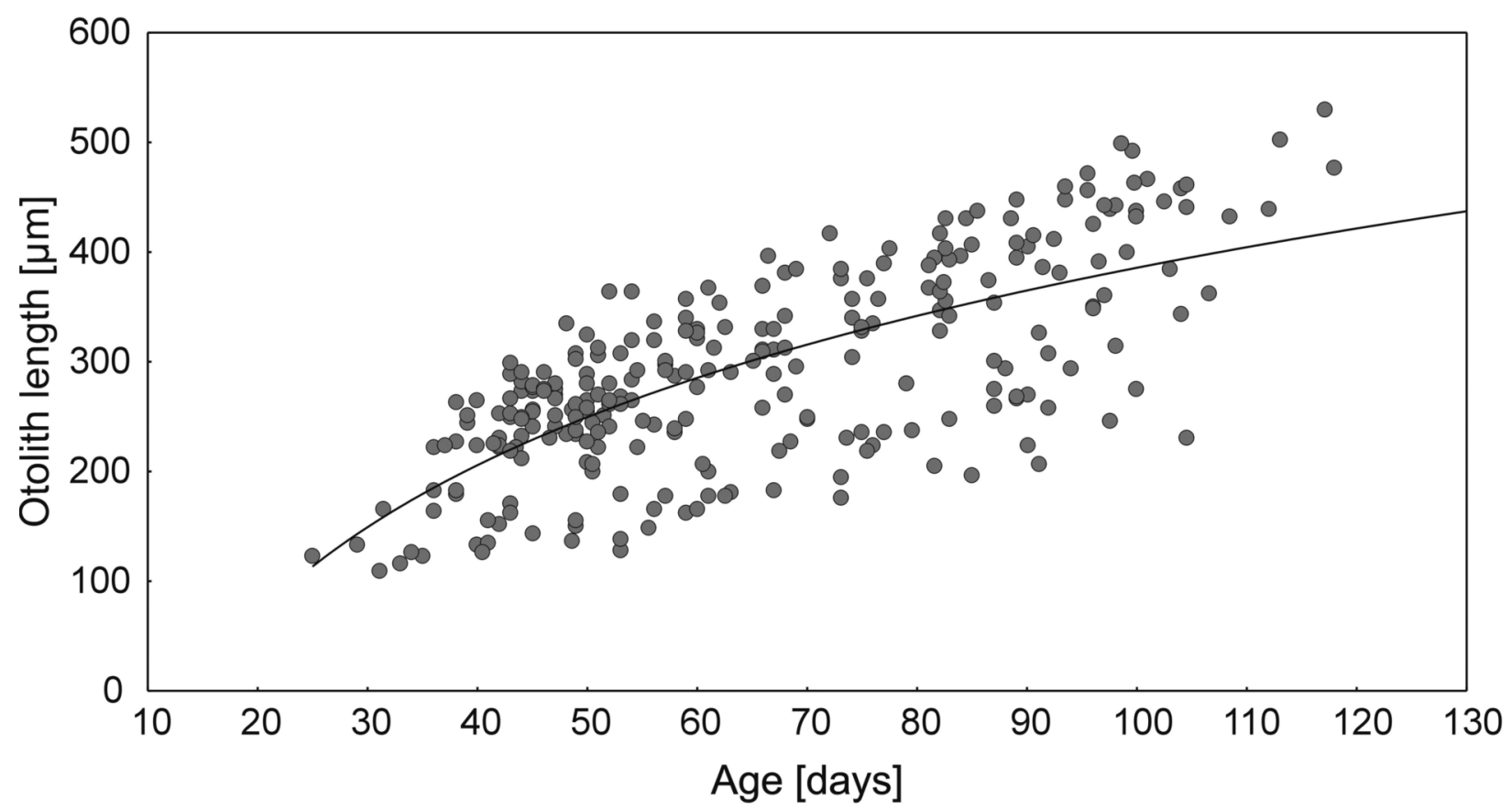

Fig. 2. Otolith size-at-age of larval Atlantic menhaden, Brevoortia tyrannus; Residuals from the fitted regression lines (otolith length $\left.=-537.03+462.83 \log (\mathrm{age}) ; n=268, r^{2}=0.526\right)$ were used as otolith growth rate indices, expressed as \% deviation from the predicted value; Only fish distinguished earlier into fast-growth rate and slowgrowth rate groups are used in this analysis 
otolith growth was significantly dependent on somatic growth. For herring, otolith growth was dependent on temperature with somatic growth having little effect.

Reports on other species and environmental factors appear to identify temperature as the main factor influencing otolith growth. Temperature was reported to elicit a strong effect in otoliths of Chinook salmon, Oncorhynchus tshawytscha (Walbaum, 1792) (see Bradford and Geen 1992), spotted sillago (=King George whiting), Sillaginodes punctatus (Cuvier, 1829) (see Barber and Jenkins 2001), Norwegian spring-spawning herring (Folkvord et al. 2004), Atlantic cod, Gadus morhua L. (see Neat et al. 2008), and (glass) Japanese eel, Anguilla japonica Temminck et Schlegel, 1846 (see Fukuda et al. 2009). Although only among slow growing menhaden, a temperature effect on otolith growth was found also in the presently reported study. Clearly, the decoupling between somatic and otolith growth is not an unusual phenomenon. Regarding other literature information available for Atlantic menhaden, temperature-influenced increment spacing in the sagittal otoliths has been reported for juveniles reared at different temperatures (Fitzhugh et al. 1997), but the effect seemed to be connected to somatic growth.

Although we found an independent temperature effect on otolith growth to be of relatively low importance overall compared to the somatic growth effect, the effect of temperature must be considered, for slow growing fish and because the cause of the temperature effect is still unclear. It was suggested by Mosegard et al. (1988) that the acceleration of otolith size is increased in higher temperature as a result of increased metabolic rate, especially if the temperature increases above optimum value for growth. For example, increase of temperature above optimum in shallow and warm waters of Vistula Lagoon was a reason of decoupling observed for Baltic herring otolith growth dependence on temperature (Fey 2005, 2006). However, this hypothesis about overoptimal temperature

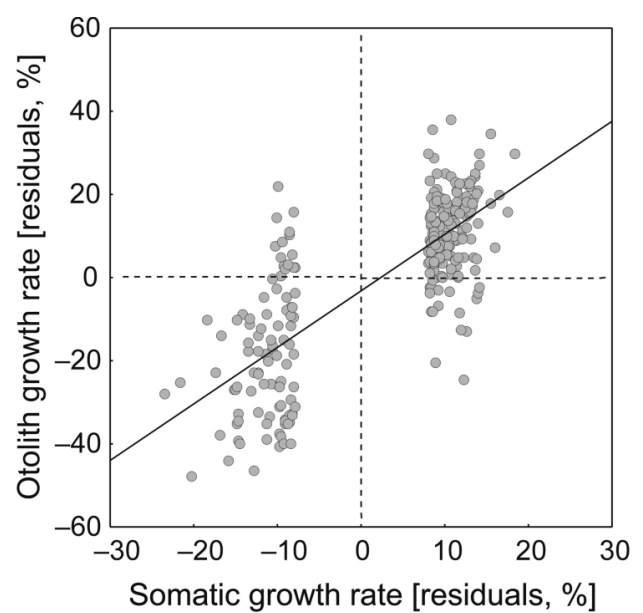

Fig. 3. The somatic growth rate (SGR) (SL-on-age residuals) effect on otolith growth rate (OGR) (otolith lengthon-age residuals) for late larval Atlantic menhaden, Brevoortia tyrannus, described with linear function $\left(\mathrm{OGR}=-3.302+1.337 \mathrm{SGR} ; n=268, r^{2}=0.576\right)$

Table 1

Analysis of variance (ANOVA) for the effect of somatic growth rate (SGR) (High-GR and Low-GR groups), temperature $\left(<15^{\circ} \mathrm{C}\right.$ and $\left.>15^{\circ} \mathrm{C}\right)$ and year $(92 / 93,93 / 04$, and 97/98) on the otolith growth rate (OGR)

\begin{tabular}{lrrrc}
\hline Fixed effect & df & \multicolumn{1}{c}{ MS } & \multicolumn{1}{c}{$F$} & $P$ \\
\hline SGR group & 1 & 64888 & 388.1 & 0.000 \\
Temperature & 1 & 6023 & 36.0 & 0.000 \\
Year & 2 & 1496 & 8.9 & 0.000 \\
SGR group $\times$ Year & 2 & 1530 & 9.2 & 0.000 \\
SGR group $\times$ Temperature & 1 & 1862 & 11.1 & 0.001 \\
Year $\times$ Temperature & 2 & 318 & 1.9 & 0.151 \\
GR group $\times$ Temperature $\times$ Year & 2 & 104 & 0.6 & 0.537 \\
Error & 260 & 167.2 & & \\
\hline
\end{tabular}

$\mathrm{df}=$ degrees of freedom, $\mathrm{MS}=$ mean square, $F=F$-ratio, $P=$ significance level.
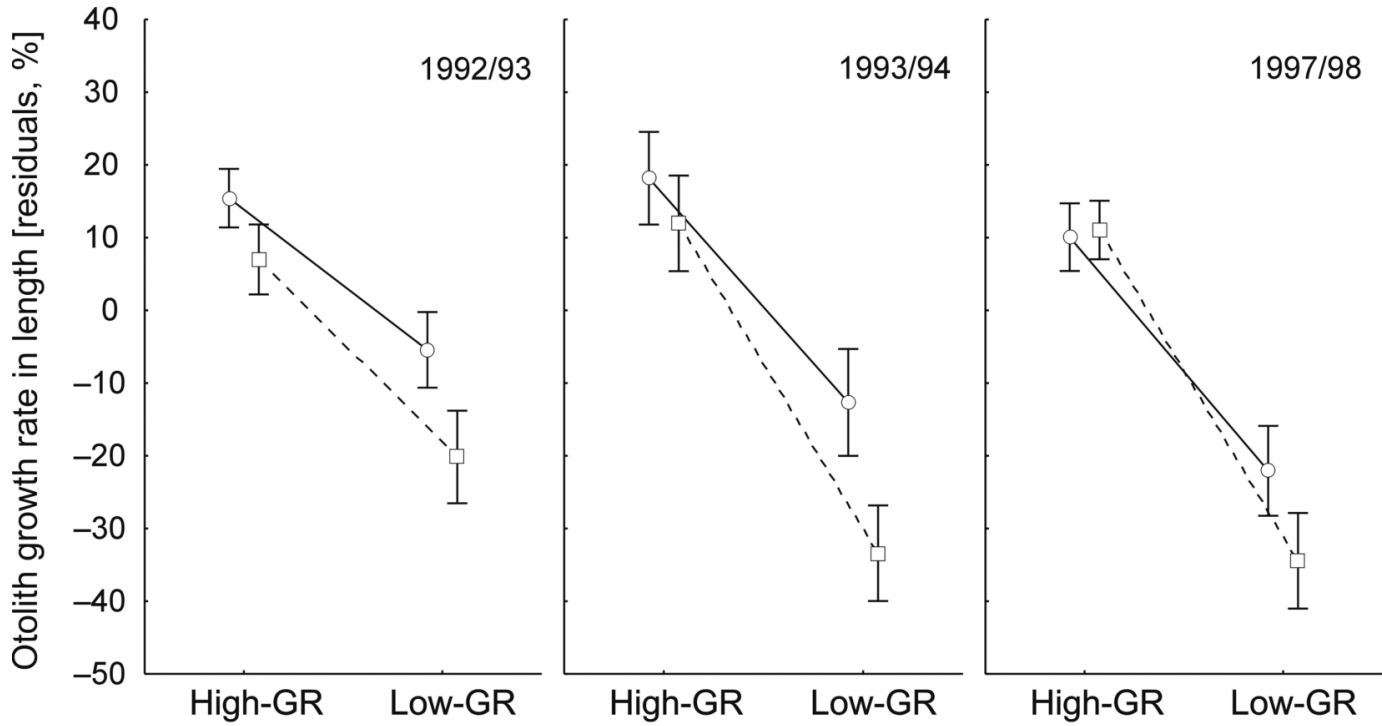

Fig. 4. Experienced temperature $\left(<15^{\circ} \mathrm{C}\right.$, squares, dashed line; $>15^{\circ} \mathrm{C}$, circles, solid line $)$ and somatic growth rate (High-GR and Low-GR) effect on the otolith growth rate (OGR) of late larval Atlantic menhaden, Brevoortia tyrannus, presented separately for three spawning seasons: 1992/93, 1993/94, and 1997/98 


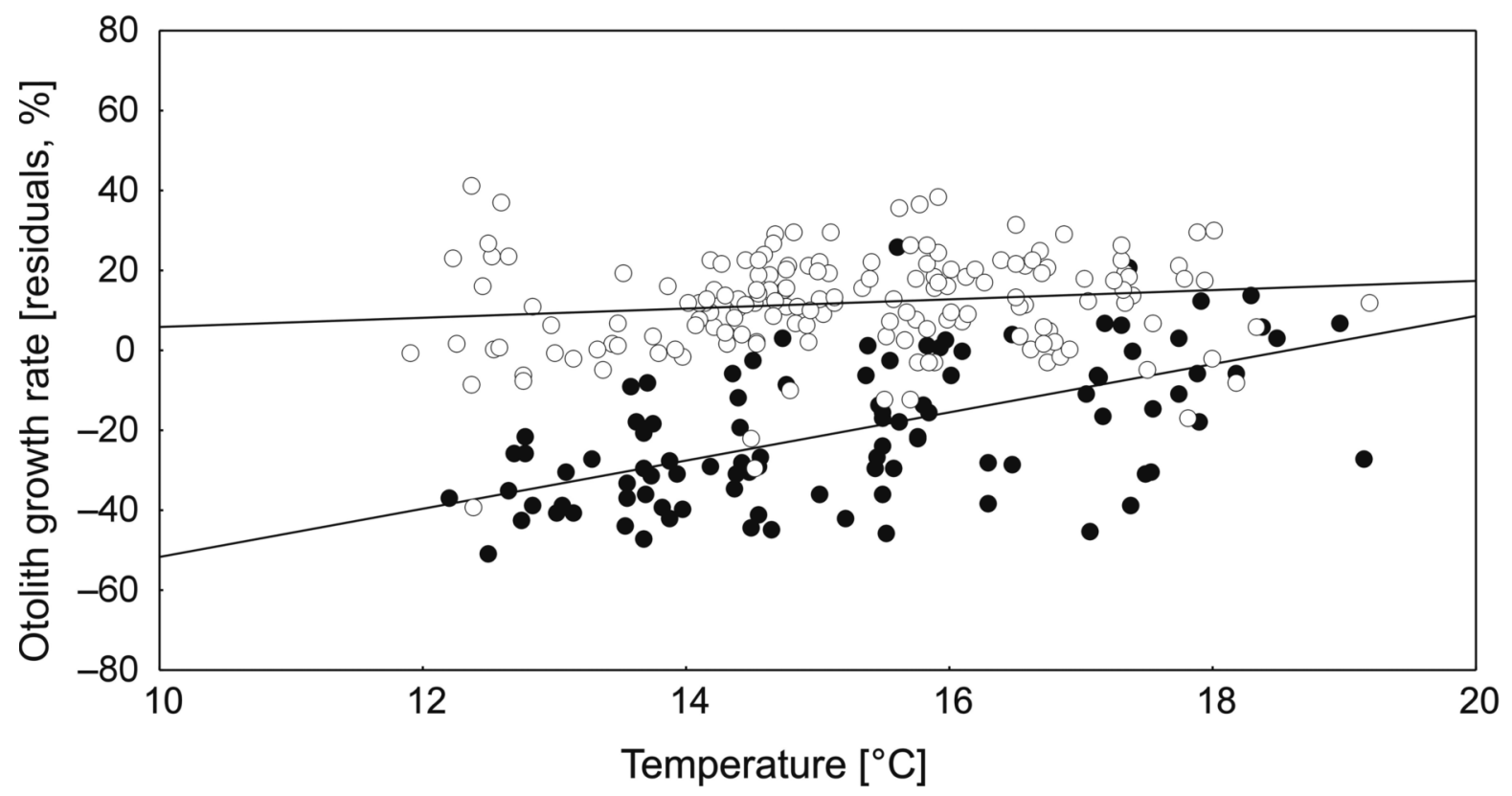

Fig. 5. The temperature $(T)$ effect on otolith growth rate (OGR) (otolith length-on-age residuals) for late larvae of Atlantic menhaden, Brevoortia tyrannus, belonging to two growth rate groups distinguished on the basis of SL-onage residuals (growth indices, $<-8 \%$ and $>8 \%$ ): fast-growth rate group (circles) (OGR $=-6.195+1.182 T ; n=167$, $\left.r^{2}=0.021, P=0.061\right)$, slow-growth-rate group (solid dots) $\left(\mathrm{OGR}=-100.1+5.628 T ; n=101, r^{2}=0.320, P<0.005\right)$

effect is perhaps invalid for menhaden in the presently reported study. Our larvae probably did not experience "untypical" temperatures (Stegmann et al. 1999), and the individuals in the fast GR group, where no temperature effect was observed, experienced the same temperatures as those from slow GR group. Mosegard et al. (1988) noted additionally that the phenomenon of metabolic rate effect on otolith growth usually relates to slow growing individuals, which agrees with our results. On the other hand, Wright (1991) reported that increment width was found to be positively correlated with the mean daily oxygen consumption in both fast growing and slow growing parr of Atlantic salmon, Salmo salar L. Also other authors (Barber and Jenkins 2001, Fukuda et al. 2009) reported from experimental studies that a positive temperature effect on otolith growth occurred in all feeding conditions analysed. The discrepancy in this issue may be to some extend related to the fact that temperature optima may not only vary for different species but also may be different for otolith and somatic growth. It is possible that in the present work temperature-induced metabolic rate increase in the group of fast-growing menhaden was mitigated by parallel somatic growth increase related to better nutritional conditions. In case of slow-growing larvae (most probably resulting from poor feeding conditions), the temperature-induced metabolic rate increase was dominant and therefore more visible.

Metabolic rate can therefore be the main factor directly controlling otolith growth, with temperature or feeding conditions being just some of the factors responsible for fish metabolism variation. For example, different temperature and feeding conditions were found by Radtke and Fey (1996) in their experimental work on Arctic charr,
Salvelinus alpinus L. responsible for parallel increase of both somatic growth and otolith growth. It is however difficult to distinguish the feeding and temperature effect on otolith growth from metabolic rate effect.

Concluding, otolith growth of larval and early juvenile menhaden was found to be significantly dependent on somatic growth, and thus the obtained results provide support for the assumptions allowing growth analysis by for example growth trajectory back-calculation or marginal increments analysis. However, some higher inaccuracy may appear for slow growing fish, where independent temperature effect on otolith growth was observed.

\section{ACKNOWLEDGMENTS}

This research was performed while the first author held a National Research Council Research Associateship Award at the NOAA Beaufort Laboratory. This paper is also a contribution to the State Committee for Scientific Research grant no 2 PO4F 02332. We thank Chris Chambers for his comments on the earlier version of this manuscript.

\section{REFERENCES}

Aguilera B., Catalán I.A., Palomera I., Olivar M.P. 2009. Otolith growth of European sea bass (Dicentrarchus labrax L.) larvae fed with constant or varying food levels. Scientia Marina 73 (1): 173-182.

DOI: $10.3989 /$ scimar.2009.73n1173

Ahrenholz D.W., Fitzhugh G.R., Rice J.A., Nixon S.W., Pritchard W.C. 1995. Confidence of otolith ageing through the juvenile stage for Atlantic menhadan, Brevoortia tyrannus. Fishery Bulletin 93 (2): 209-216.

Ahrenholz D.W., Squires D.D., Rice J.A., Nixon S.W., Fitzhugh G.R. 2000. Periodicity of increment formation in 
otoliths of overwintering postlarval and prejuvenile Atlantic menhaden, Brevoortia tyrannus. Fishery Bulletin 98 (2): 421-426.

Anderson J.T. 1988. A review of size dependent survival during pre-recruit stages of fishes in relation to recruitment. Journal of Northwest Atlantic Fisheries Science 8: 55-66.

Barber M.C., Jenkins G.P. 2001. Different effects of food and temperature lead to decoupling of short-term otolith and somatic growth rates in juvenile King George whiting. Journal of Fish Biology 58 (5): 1320-1330. DOI: $10.1111 /$ j.1095-8649.2001.tb02289.x

Bradford M.J., Geen G.H. 1992. Growth estimates from otolith increment widths of juvenile chinook salmon (Oncorhynchus tshawytscha) reared in changing environments. Journal of Fish Biology 41 (5): 825-832. DOI: $10.1111 /$ j.1095-8649.1992.tb02710.x

Campana S.E. 2005. Otolith science entering the 21 st century. Marine and Freshwater Research 56 (5): 485-495. DOI: 10.1071/MF04147

Campana S.E., Neilson J.D. 1985. Microstructure of fish otoliths. Canadian Journal of Fisheries and Aquatic Sciences 42 (5): 1014-1032. DOI: $10.1139 / \mathrm{f} 85-127$

Clemmesen C.M. 1988. A RNA and DNA fluorescence technique to evaluate the nutritional condition of individual marine fish larvae. Meeresforschung 32: 134-143.

Fey D.P. 2001. Differences in temperature conditions and somatic growth rate of larval and early juvenile spring-spawned herring from the Vistula Lagoon, Baltic Sea manifested in the otolith to fish size relationship. Journal of Fish Biology 58 (5): 1257-1273. DOI: 10.1111/j.1095-8649.2001.tb02284.x.

Fey D.P. 2005. Is the marginal otolith increment width a reliable recent growth index for larval and juvenile herring? Journal of Fish Biology 66 (6): 1692-1703. DOI: $10.1111 / \mathrm{j} .0022-1112.2005 .00716 . x$

Fey D.P. 2006. The effect of temperature and somatic growth on otolith growth: the discrepancy between two clupeid species from a similar environment. Journal of Fish Biology 69 (3): 794-806. DOI: 10.1111/j.1095-8649.2006.01151.x

Fey D.P., Hare J.A. 2005. Length correction of larval and earlyjuvenile Atlantic menhaden (Brevoortia tyrannus) after preservation in alcohol. Fishery Bulletin 103 (4): 725-727.

Fey D.P., Hare J.A. 2008. Fluctuating asymmetry in the otoliths of larval Atlantic menhaden Brevoortia tyrannus (Latrobe) - a condition indicator? Journal of Fish Biology 72 (1): 121-130. DOI: $10.1111 /$ j.1095-8649.2007.01684.x

Finstad A.G. 2003, Growth backcalculation based on otoliths incorporating an age effect: adding an interaction term. Journal of Fish Biology 62 (5): 1222-1225.

DOI: $10.1046 / j .1095-8649.2003 .00102 . x$

Folkvord A., Johannessen A., Moksness E. 2004. Temperature-dependent otolith growth in Norwegian spring-spawning herring (Clupea harengus L.) larvae. Sarsia 89 (5): 297-310.

DOI: $10.1080 / 00364820410002532$

Folkvord A., Ystanes L., Johannessen A., Moksness E. 1996. RNA : DNA ratios and growth of herring (Clupea harengus) larvae reared in mesocosms. Marine Biology 126 (6): 591-602.

DOI: $10.1007 / \mathrm{BF} 00351326$

Fitzhugh G.R., Nixon S.W., Ahrenholz D.W., Rice J.A. 1997. Temperature effects on otolith microstructure and birth month estimation from otolith increment patterns in Atlantic menhaden. Transactions of the American Fisheries Society 126 (4): 579-593.

Francis R.I.C. 1990. Back-calculation of fish length: a critical review. Journal of Fish Biology 36 (6): 883-902. DOI: $10.1111 / j .1095-8649.1990 . t b 05636 . x$

Fuiman L.A., Werner R.G. 2002. Fishery science: The unique contributions of early life stages. Blackwell Science, Oxford, UK.

Fukuda N., Kuroki M., Shinoda A., Yamada Y., Okamura A., Aoyama J., Tsukamoto K. 2009. Influence of water temperature and feeding regime on otolith growth in Anguilla japonica glass eels and elvers: does otolith growth cease at low temperatures? Journal of Fish Biology 74 (9): 1915-1933.

DOI: $10.1111 / \mathrm{j} .1095-8649.2009 .02287 . \mathrm{x}$

Hare J.A., Cowen R.K. 1995. Effect of age, growth rate, and ontogeny on the otolith size - fish size relationship in bluefish, Pomatomus saltatrix, and the implications for back-calculation of size in fish early life history stages. Canadian Journal of Fisheries and Aquatic Sciences 52 (9): 1909-1922.

DOI: $10.1139 / \mathrm{f} 95-783$

Hare J.A., Cowen R.K. 1997. Size, growth, development, and survival of the planktonic larvae of Pomatomus saltatrix (Pisces: Pomatomidae). Ecology 78 (8): 2415-2431.

DOI: 10.1890/0012-9658(1997)078[2415:SGDASO]2.0.CO;2

Håkanson J.L. 1989. Condition of larval anchovy (Engraulis mordax) in the Southern California Bight, as measured through lipid analysis. Marine Biology 102 (2): 153-159. DOI: 10.1007/BF00428275

Houde E.D. 1987. Fish early life dynamics recruitment variability. American Fisheries Society Symposium 2: 17-29.

Maillet G.L., Checkley D.M. jr. 1990. Effects of starvation on the frequency of formation and width of growth increments in sagittae of laboratory-reared Atlantic menhaden Brevoortia tyrannus larvae. Fishery Bulletin 88 (1): 155-165.

Maillet G.L., Checkley D.M.jr. 1991. Storm-related variation in the growth rate of otoliths of larval Atlantic menhaden Brevoortia tyrannus: a time series analysis of biological and physical variables and implications for larva growth and mortality. Marine Ecology Progress Series 79 (1): 1-16. DOI: 10.3354/meps079001

McCormick M.I., Molony B.W. 1992. Effects of feeding history on the growth characteristics of a reef fish at settlement. Marine Biology 114 (1): 165-173.

DOI: $10.1007 /$ BF00350866

Meekan M.G., Fortier L. 1996. Selection for fast growth during the larval life of Atlantic cod Gadus morhua on the Scotian Shelf. Marine Ecology Progress Series 137 (1-3): 25-37.

DOI: $10.3354 /$ meps 137025

Molony B.W., Choat J.H. 2006. Otolith increment widths and somatic growth rate: the presence of a time-lag. Journal of 
Fish Biology 37 (4): 541-551.

DOI: $10.1111 / j .1095-8649.1990 . t b 05887 . x$

Morita K., Matsuishi T. 2001. A new model of growth back-calculation incorporating age effect based on otoliths. Canadian Journal of Fisheries and Aquatic Sciences 58 (9): 1805-1811. DOI: $10.1139 / \mathrm{f01}-126$

Mosegaard H., Svedäng H., Taberman K. 1988. Uncoupling of somatic and otolith growth rates in arctic char (Salvelinus alpi$n u s)$ as an effect of differences in temperature response. Canadian Journal of Fisheries and Aquatic Sciences 45 (9): 1514-1524. DOI: $10.1139 / \mathrm{f} 88-180$

Mugiya Y., Oka H. 1991. Biochemical relationship between otolith and somatic growth in the rainbow trout Oncorhynchus mykiss: consequence of starvation, resumed feeding, and diel variations. Fishery Bulletin 89 (2): 239-245.

Neat F.C., Wright P.J., Fryer R.J. 2008. Temperature effects on otolith pattern formation in Atlantic cod Gadus morhua. Journal of Fish Biology 73 (10): 2527-2541. DOI: $10.1111 /$ j.1095-8649.2008.02107.x

Oozeki Y., Watanabe Y. 2000. Comparison of somatic growth and otolith increment growth in laboratory-reared larvae of Pacific saury, Cololabis saira, under different temperature conditions. Marine Biology 136 (2): 349-359. DOI: $10.1007 / \mathrm{s} 002270050693$

Palmer A.R. 1994. Fluctuating asymmetry analyses: A primer. Pp. 335-364. In: Markow T.A. (ed.) Developmental instability: Its origins and evolutionary implications. Kluwer, Dordrecht, the Netherlands.

Paperno R., Targett T.E., Grecay P.A. 1997. Daily growth increments in otoliths of juvenile weakfish, Cynoscion regalis: experimental assessment of changes in increment width with changes in feeding rate, growth, and condition factor. Fishery Bulletin 95 (3): 521-529.

Radtke R., Fey D.P. 1996. Environmental effects on primary increment formation in the otoliths of newly-hatched Arctic charr. Journal of Fish Biology 48 (6): 1238-1255. DOI: $10.1111 / j .1095-8649.1996 . t b 01818 . x$

Secor D.H., Dean J.M. 1992. Comparison of otolith-based backcalculation methods to determine individual growth histories of larval striped bass, Morone saxatilis. Canadian Journal of Fisheries and Aquatic Sciences 49 (7): 1439-1454. DOI: $10.1139 / \mathrm{f} 92-159$

Secor D.H., Dean J.M., Baldevarona R.B. 1989. Comparison of otolith growth and somatic growth in larval and juvenile fishes based on otolith length/fish length relationships. Rapports et Procés-Verbaux des Réunions du Conseil International pour l'Exploration de la Mer 191: 431-438.

Sirois P., Lecomte F., Dodson J.J. 1998. An otolith-based backcalculation method to account for time-varying growth rate in rainbow smelt (Osmerus mordax) larvae. Canadian Journal of Fisheries and Aquatic Sciences 55 (12): 2662-2671.

DOI: $10.1139 /$ cjfas-55-12-2662

Sogard S.M. 1991. Interpretation of otolith microstructure in juvenile winter flounder (Pseudopleuronectes americanus): ontogenetic development, daily increment validation, and somatic growth relationships. Canadian Journal of Fisheries and Aquatic Sciences 48 (10): 1862-1871.

DOI: $10.1139 / \mathrm{f} 91-220$
Stegmann P.M., Quinlan J.A., Werner F.E., Blanton B.O., Berrien P. 1999. Atlantic menhaden recruitment to a southern estuary: defining potential spawning regions. Fisheries Oceanography 8 (Suppl. s2): 111-123. DOI: $10.1046 /$ j.1365-2419.1999.00022.x

Takasuka A., Oozeki Y., Aoki I., Kimura R., Kubota H., Sugisaki H., Akamine T. 2008. Growth effect on the otolith and somatic size relationship in Japanese anchovy and sardine larvae. Fisheries Science 74 (2): 308-313. DOI: $10.1111 /$ j.1444-2906.2008.01519.x

Takasuka A., Oozeki Y., Kimura R., Kubota H., Aoki I. 2004. Growth-selective predation hypothesis revisited for larval anchovy in offshore waters: cannibalism by juveniles versus predation by skipjack tunas. Marine Ecology Progress Series 278: 297-302.

DOI: $10.3354 / \operatorname{meps} 278297$

Theilacker G.H. 1986. Starvation-induced mortality of young sea-caught jack-mackerel, Trachurus symmetricus, determined with histological and morphological methods. Fishery Bulletin 84 (1): 1-17.

Thorrold S.R., Hare J.A. 2002. Otolith applications in reef fish ecology. Pp. 243-264. In: Sale P.F. (ed.) Advances in the ecology of fishes on coral reefs. Academic Press, San Diego, California, USA.

Tonkin Z., King A.J., Ramsey D.S.L. 2008. Otolith increment width responses of juvenile Australian smelt Retropinna semoni to sudden changes in food levels: the importance of feeding history. Journal of Fish Biology 73 (4): 853-860. DOI: $10.1111 / \mathrm{j} .1095-8649.2008 .01976 . \mathrm{x}$

Quinlan J.A., Blanton B.O., Miller T.J., Werner F.E. 1999. From spawning grounds to the estuary: using linked individual-based and hydrodynamic models to interpret patterns and processes in the oceanic phase of Atlantic menhaden Brevoortia tyrannus life history. Fisheries Oceanography 8 (Suppl. s2): 224-246. DOI: $10.1046 /$ j.1365-2419.1999.00033.x

Wang Y.-T., Tzeng W.-N. 1999. Differences in growth rate among cohorts of Encrasicholina punctifer and Engraulis japonicus larvae in the coastal waters off Tanshui River Estuary, Taiwan, as indicated by otolith microstructure analysis. Journal of Fish Biology 54 (5): 1002-1016. DOI: 10.1111/j.1095-8649.1999.tb00853.x

Warlen S.M. 1992. Age, growth, and size distribution of larval Atlantic menhaden off North Carolina. Transactions of the American Fisheries Society 121 (5): 588-598.

DOI: 10.1577/1548-8659(1992)121<0588:AGASDO >2.3.CO;2

Warlen S.M. 1994. Spawning time and recruitment dynamics of larval Atlantic menhadan, Brevooria tyrannus, into a North Carolina estuary. Fishery Bulletin 92 (2): 420-433.

Wright P.J. 1991. The influence of metabolic rate on otolith increment width in Atlantic salmon parr, Salmo salar L. Journal of Fish Biology 38 (6): 929-933.

DOI: 10.1111/j.1095-8649.1991.tb03632.x

Received: 24 February 2012

Accepted: 20 August 2012

Published electronically: 30 September 2012 